\title{
The conditional gender wage gap in Egypt: premium or penalty?
}

Hanan Nazier

Cairo University, hanan.nazier@feps.edu.eg

Follow this and additional works at: https://ecommons.luc.edu/meea

\section{Recommended Citation}

Nazier, Hanan, "The conditional gender wage gap in Egypt: premium or penalty?". Topics in Middle Eastern and North African Economies, electronic journal, 19, 2, Middle East Economic Association and Loyola University Chicago, 2017, http://www.luc.edu/orgs/meea/

This Article is brought to you for free and open access by the Journals and Magazines at Loyola eCommons. It has been accepted for inclusion in Topics in Middle Eastern and North African Economies by an authorized administrator of Loyola eCommons. For more information, please contact ecommons@luc.edu. (c) (i) (2)

This work is licensed under a Creative Commons Attribution-Noncommercial-No Derivative Works 3.0 License. (C) 2017 The Authors 


\title{
The conditional gender wage gap in Egypt: premium or penalty?
}

\author{
Hanan Nazier ${ }^{1}$
}

\begin{abstract}
This paper examines the gender wage gaps along the wage distribution in Egypt using individual data from the labor market panel surveys 1998, 2006 and 2012 and a quantile regression approach. Results show that in average female's hourly wage is significantly less than that of males. While the wage gap in average is in favor of men it is decreasing with time and with education. Across quantiles the effect of being a female on hourly wages is negative, however this gap is higher at the lower and highest quantiles as compared to the middle ones. Indicating the presence of glass ceiling as well as sticky floors. Results also showed that household characteristics and location matter for the gap at higher quintile i.e. for the glass ceiling phenomena while the gap at the lower quantiles i.e. the sticky floor could be attributed to other unobservable related to location and social context. In societies like Egypt social context may enable males to compete better in the labor market. Hence resulting in women being paid less. Thus, key policy options must include not simply the usual policies to improve women's productivity but policies that promote gender equity in hiring, and in the workplace. Moreover, policy options need to be extended out of the labor market and into the household to help women overcome unobservable that trap them in low-paying jobs.
\end{abstract}

Keywords: Gender wage gap, quintile regression, glass ceilings, sticky floors, Egypt, ELMPS.

JEL Classifications: J16, J31, J71, J40

\footnotetext{
${ }^{1}$ Associate professor at the Faculty of Economics and Political Science- Cairo University, Egypt E-mail: hanan.nazier@feps.edu.eg
} 


\section{1- Introduction}

There is a common agreement among researchers that observed labor market outcomes differ by gender in most developing economies. These differences include rates of participation in labor force, occupational choice, sectoral allocation, unemployment rate, as well as wage distribution. Mainly wages are key indicators of economic well-being and of individual accomplishment. Therefore, the level of women's relative to men's pay is an informative indicator about both women's progress in the labor market and their status in the household (El-Hamidi, and Said, 2008).

The gender wage gap points to women's disadvantage in earned income relative to men. This gap reveals implicit and explicit discrimination practices in employment and wages. Wage based discrimination arises when workers with identical productivity characteristics receive unequal treatment in reward (El-Hamidi, and Said, 2008).

The gender wage discrimination favoring men is well documented in several studies (Anker, 1997; Ashraf and Ashraf, 1998; Hampton and Heywood, 1993; Hoffner and Greene, 1997; Francois, 1995; Ermisch et al., 1990; Nor, 1998; Teo and Bhattarcherjee, 1998; Schafgans, 1997; Weeden, 1998; Wright and Ermish, 1990; Terrell, 1992; Harkness, 1996; Stephen, 1998; Teo, 2003 and Poulakis, 2012). Gender wage differences appear to occur in many countries to some extent.

Gender differences are often documented by the ratio of female and male wages. Statistics on wages show that female/male earnings ratios are commonly less than one, indicating that females usually earn less than males do (Kara, 2006). However this does not explain how much of this difference could be attributed only to being a female or male.

Hence, several studies have been dedicated to examining the extent of the discrimination and its possible explanations. In this context human capital theory has become the most frequently employed economic model for explaining labor market outcomes, starting with the pioneering work by Schultz $(1959,1960$, and 1961). According to this theory, productivity is mainly 
Topics in Middle Eastern and African Economies

Proceedings of Middle East Economic Association

Vol. 19, Issue No. 2, September 2017

determined by the stock of human capital of a worker. Human capital mainly results from formal education and work experience, which affect productivity, and in turn affect earnings. In addition, other variables are found to have significant effect on wages and consequently are also very important in explaining the wage differences. Those include occupation, industry, and sector ownership (Derek, 1998; Elizabeth, 1998; Terrell, 1992). Then, the unexplained part can be attributed to gender differences (Kara, 2006).

Recently, research has focused on examining the gender wage gap along the whole wage distribution. Those studies have confirmed that gender wage gap may differ along the wage distribution. In this context one can distinguish between "glass ceilings" and "sticky floors". In some countries, females experience glass ceilings as demonstrated by larger gender gaps at the top of the wage distribution. In others, they face sticky floors where gender gaps are higher at the bottom of the wage distribution (Aktas and Uysal 2012 and Albrecht et al. 2003). Thus, higher wage gaps, conditional on covariates at the top of the wage distribution are consistent with the presence of 'glass ceilings', while pay gaps that expand at the bottom of the distribution, reflect 'sticky floors,' or "glass ceilings at the ground floor" (Arulampalam et al. 2006, Albrecht et al. 2003, de la Rica et al. 2005 and Aktas and Uysal 2012). Accordingly it's interesting to, study the gender gap along the wage distribution.

Glass ceiling can be explained by the unequal allocation of 'good' jobs (high paying), which are in short supply (Pendakur and Pendakur 2007). Typically, this is understood to mean that when there are two or more groups of unequal status in the labor market, the inferior group will have earnings distributions, which look similar to the dominant group over ordinary jobs, but are comparatively thin over high-paying jobs. Likewise 'sticky floors' may arise because the wage distribution reflects labor market segmentation, with informal jobs occupying the lower end of the distribution (Tannuri-Pianto, Pianto and Arias 2004). In this context, sticky floors reflect the presence of barriers against access to 'good jobs' for disadvantaged groups. Moreover, 'sticky floors' may happen even in regulated labor markets with anti-discrimination legislation. In this case, sticky floors may arise due to the fact that "only the more articulate and better educated are willing to take legal action against violations of the law", because men are initially appointed at a higher starting salary within a particular scale, or because women 
Topics in Middle Eastern and African Economies

Proceedings of Middle East Economic Association

Vol. 19, Issue No. 2, September 2017

at the lower end have less bargaining power compared to men due to family obligations or social traditions (Arulampalam et al. 2006 and Gunewardena et. al 2008).

Accordingly, knowing where the unexplained gender wage gaps occur in the wage distribution, and how their magnitude differs along the distribution, is crucial to enhance our understanding of the gender discrimination in the labor market and to design more effective policies to lessen or eradicate it. For instance, policies intended to tackle discrimination have both equity and efficiency gains. The equity gains will be even higher if analysis reveals gender disparities to be larger at the bottom of the distribution. Counterfactual analysis based on quantile regression makes such an analysis possible.

Evidence on gender wage gap in the Middle East and North Africa region MENA, including Egypt, goes in line with the international literature. Two important remarks are worth noting in this regard. That evidence reported gender-based occupational segregation in the labor markets (Aktas, and Uysal 2012; Kandil, 2009; Kara 2006; El-Hamidi, and Said 2008). Occupational segregation exists when women dominate in certain occupations and men in others, resulting in lower earnings and in efficiency loss (lower productivity). Labor laws, tradition, social pressure and commitment to the family may forbid women from occupying certain jobs that are considered dangerous or that require work at night, or may discourage women from taking better paid jobs, and thus confining themselves to particular employment opportunities. Accordingly, occupational segregation plays a very important role in the size of the gender pay gap in MENA countries (El-Hamidi and Said, 2008).

Moreover, sector ownership is considered to be particularly important in MENA countries in general and in Egypt in specific where public sector usually comprises a major part of the wage employment (Tansel, 2004). Therefore, it could influence the wage setting and other employment practices in the rest of the labor market including the gender wage gap. Given the large role of the state as an employer in the MENA region the gender wage gap has often been explored across public-private divide for those countries (Tansel 2004; Said 2003; El-Hamidi and Said 2005; Said 2007, El-Hamidi, and Said 2008; Said 2015).

In this context the study is an attempt to examine whether 'sticky floors' and/or 'glass ceilings', 
Topics in Middle Eastern and African Economies

Proceedings of Middle East Economic Association

Vol. 19, Issue No. 2, September 2017

characterize the Egyptian labor market using quantile regression analysis. It also tries to analyze main determinants of gender-based wage discrimination (El-Hamidi and Said 2008) in Egypt over a period (1998 to 2012). The study adds to previous literature on Egypt by covering some of the gaps that were identified as explained in what follows as well as covering the period from 2006 to 2012 which is a time of significant economic and political changes, including the recent global financial crises and the January 25th 2011 revolution (Said 2015).

Several previous studies have estimated the gender wage gap in the Egyptian case (El-Hamidi and Said 2008 and 2005; Arabsheibani 2000; Kandil 2009; Said 2003; Said 2015). However most of those studies suffer from at least one of the following shortcomings that I simultaneously address in the present study.

First, most studies focus on comparisons at the mean. This hides important information and may explain -in addition to the use of different methodologies and sample selection - the difficulty to reconcile the different estimates obtained in the literature. Although few studies employed quintile estimations to estimate gender wage gaps along the conditional wage distribution (Kandil, 2009; Said 2003), however this study use more updated data that account for recent developments in Egypt especially January 25th 2011 revolution.

Second, none of the previous studies accounted for the impact of traditions and social pressure on the gender gap. Social norms are crucial in shaping women's activities. Ideas, norms and values of the society about women's mobility and employment may affect women's decision to go out of the house to work as well as the wage level they receive. Therefore variables capturing where a woman lives should be taken into account in the model.

Accordingly the proposed study is an attempt to fill in these gaps in the literature. In the present paper, I adopt Quintile Regression (QR). Estimations of the mean gap, as suggested in several studies and for several countries (Badaoui et al., 2008, for South Africa), conceal the variety of situations that may exist. Instead, the present paper suggests using quintile regression $(\mathrm{QR})$ to assess female wage gaps at different points along the conditional wage distribution. Moreover, in addition to individual and households characteristics, the model will include locational variables to reflect the social context where the wageworker lives. The paper is 
Topics in Middle Eastern and African Economies

Proceedings of Middle East Economic Association

Vol. 19, Issue No. 2, September 2017

organized as follows; section 2 describes the methodology. Section 3 presents the data and data description in addition to a brief discussion of the raw wage gap. The estimated results are discussed in section 5 and finally section 6 concludes.

\section{2- Methodology}

This study uses a quantile regression model as introduced in Koenker and Bassett (1978) to describe the conditional wage distribution. By construction, using OLS regression to study the gender wage gap focus on the mean of the wage distribution where the marginal returns to different covariates are estimated only at the mean. Nevertheless, the effects of those covariates can differ along the conditional wage distribution. Recently, quantile regression (QR) techniques are used for examine the effects of the covariates on log wages at different quantiles of the wage distribution (Aktas and Uysal, 2012).

QR is more flexible than OLS and allows studying the effects of covariates on the whole conditional distribution of the dependent variable. This is especially useful when studying the gender wage gaps, as data suggests that gender-earnings differentials involve more than just that males, on average, earn more than females.

Quantile regressions are an extension of the least squares estimation of conditional mean models to the estimation of a group of models of conditional quantile functions - of which the default is the median regression estimator or Least Absolute Deviations (LAD) estimator that minimizes a sum of absolute errors (Koenker and Hallock 2001 and Gunewardena et. al 2008). Thus offering a more detailed examination of the conditional wage distribution. In contrast to the OLS the QR methods are preferred since they initial a higher degree of robustness in estimation as it is less sensitive to outliers (Koenker and Bassett, 1978) and can detect and correct (in combination with bootstrap methods) for heteroskedasticity (Deaton, 1997). As in ordinary least squares regression, where the mean of the distribution of the dependent variable, which is log wage of worker i in our case, is modeled conditional on the regressors, quantile regressions yield models for different percentiles of the distribution.

For any worker $\mathrm{i}$, the $\tau^{\text {th }}$ quantile of the wage distribution, conditionally on the observables, can be written as a linear function of the regression variable, $\mathrm{X}$ as follows: 


$$
Q_{\tau}\left(\ln w_{i} \mid x_{i}\right)=X_{i} \beta_{\tau}+I_{i} \delta(\tau) \quad \forall \tau \in[0,1]
$$

Where $w_{i}$ is the wage of individual i, $x_{i}$ is the set of covariates that will be used in the model and the coefficient $\beta_{\tau}$ is the slope of the quantile line giving the effects of changes in $X$ on the $\tau^{\text {th }}$ conditional quantile of $\ln w$.

The covariates include individual characteristics such as age, age squared, education level, marital status, sector of employment, and parent's education. The model includes as well households' characteristics such as the household size, and number of durable goods.

Moreover, the model will include variables reflecting the social context,that is captured by urban/rural dummy and regional dummies.

The conditional wage gap between men and women is captured by a dummy variable $I_{i}$, that equals 1 if the individual is a women, 0 otherwise. And, $\delta(\tau)$ measures the gender premium/penalty at the $\tau^{\text {th }}$ quantile.

As shown by Koenker and Basset (1978), the model can be estimated by finding the vector $\beta_{\tau}$ that minimizes the following:

$$
\beta_{\tau}=\operatorname{argmin}\left[\sum_{i: y_{i} \geq X, \beta} \tau\left|w_{i}-X_{i} \beta\right|+\sum_{i: y_{i}<X, \beta}(1-\tau)\left|w_{i}-X_{i} \beta\right|\right]
$$

Coefficients of quantile regressions are interpreted in the usual way. Standard errors are bootstrap standard errors (Gunewardena et. al 2008).

Three version of the model are estimated. The first and the main model is one that includes all three groups of regressors: individual characteristics, household characteristics and regions. The second model includes only individual characteristics as regressors while the third one includes household characteristics as well. The intuition behind estimating those three versions of the model is to compare the results concerning the effect of gender on wages when using less number of observables and also to compare the significance of the quintile regression estimated coefficients from the OLS ones. 
One concern in the adopted methodology is the selectivity bias in the labor force participation choice in addition to in the selection into wage employment. Selectivity-correction techniques for mean regression are common, though accurate empirical estimation is often difficult due to issues relating to identifying instruments or exclusion restrictions. However, techniques to correct for selectivity bias in quantile regression models are less common and there is little consent regarding the most proper correction technique. Given the lack of sufficiently good instruments for a labor market participation decision or wage employment in our sample, the trade-off in using potential instead of actual experience in the selectivity corrected model, and the added complications that arise in correcting for selectivity bias in quantile regression models, This paper follows a strand of studies and adopt no selection correction technique in either the ols or quantile regression models (de la Rica, et. al 2005 Pham and Reilly 2006; Newell and Reilly 2001; Montenegro 2001; Said 2003 ;Sakellariou 2004 and Gunewardena et. al 2008). Accordingly, results of this study should be interpreted as being conditional on the selected samples. Moreover in the absence of selectivity correction, the coefficients in the regressions are biased estimates of returns to covariates. Hence they are the returns to covariates of the given samples, and cannot be applied to the working age population in general.

\section{3- Data:}

The analysis utilize cross-sectional data from three comparable Egyptian labor market surveys: The Egyptian Labor Market Survey ELMS 1998, and The Egyptian Labor Market Panel Survey ELMPS for 2006 and 2012. The Egypt Labour Market Panel Survey, carried out by the Economic Research Forum (ERF) in cooperation with Egypt's Central Agency for Public Mobilization and Statistics (CAPMAS) since 1998, has become the mainstay of labor market and human resource development research in Egypt, being the first and most comprehensive source of publicly available micro data on the subject.

The ELMPS is a wide-ranging, nationally representative panel survey that covers topics such as parental background, education, housing, access to services, residential mobility, migration and remittances, time use, marriage patterns and costs, fertility, women's decision making and 
Topics in Middle Eastern and African Economies

Proceedings of Middle East Economic Association

Vol. 19, Issue No. 2, September 2017

empowerment, job dynamics, savings and borrowing behaviour, the operation of household enterprises and farms, besides the usual focus on employment, unemployment and earnings in typical labor force surveys.

The first round of the panel, the Egypt Labor Market Survey of 1998 (ELMS 1998) was carried out on a nationally representative sample of 4,816 households containing 23,997 individuals. The ELMPS 2006 followed the initial ELMS 1998 sample, locating 3,685 households from the original ELMS 1998 survey and adding 2,168 new households that emerged from these households as a result of splits, as well as a refresher sample of 2,498 households, all totalling 8,351 households containing 37,140 individuals. The ELMPS 2012 is the third round of a periodic longitudinal survey that tracks the labor market and the demographic characteristics of households and individuals interviewed in 2006, both individuals included in the ELMS 1998 and individuals added in 2006, as well as a refresher sample of 2,000 new households to ensure that the data continues to be nationally representative, a total sample of 12,060 households and 49,186 individuals. The 2012 round of the survey provides a unique opportunity to ascertain the impact of the momentous events accompanying the January 25 th revolution on the Egyptian economy and labour market and on the lives of Egyptian workers and their families.

\section{3-1 Data Description and the Raw Wage Gap}

Table 1 describes the selected samples. Focusing on wageworkers leaves a total sample size of 27,022 observations of which 21,697 are males accounting for $80.3 \%$ of the sample. Indeed, women who are self-employed and unpaid family workers, excluded from our final sample, represents majority of employed females in Egypt. Females have an average age of 35.3 years old while the average age for males is 35.2 years old. Females have higher years of schooling in average (around 13 years as compared to 10 years for males). The majority of females (74\%) work in the public sector while only $41 \%$ of males work in the public sector.

Table 1 shows that hourly wages are on average larger for females than males, however the difference is very moderate only 0.25 points. Table 2 shows hourly wages for females and males along the five quantiles of the wage distribution, its noticeable that at all five quantiles 
Topics in Middle Eastern and African Economies

Proceedings of Middle East Economic Association

Vol. 19, Issue No. 2, September 2017

hourly wages for females is lower than males. The table also shows that the difference increases as we move from lower quintiles to higher ones. Looking at figures 1 and 2 confirm that and uncover an important fact; although the median of hourly wages is very close for both females and males and the gap between hourly wages for males and females is relatively small at the lower quintiles of the wage distribution while there is a big difference at the $90^{\text {th }}$ quantile. Hourly wages for females vary between 0.4 and 300 while that for males varies between 0.2 and 800 . We have very low wages at lower quantiles for both males and females however it rapidly increases as we get towards the $90^{\text {th }}$ quantile with a major higher maximum value for males.

Table 1: Selected Samples: Descriptive Statistics

\begin{tabular}{lrrr}
\hline Variable & \multicolumn{1}{l}{ Females } & \multicolumn{1}{l}{ Males } & \multicolumn{1}{l}{ All sample } \\
\hline & & & \\
\hline Log hourly wages & 0.6390207 & 0.7792986 & 0.7515001 \\
\hline Hourly wages & 3.600285 & 3.849459 & 3.800081 \\
\hline Age & 35.33784 & 35.19994 & 35.22711 \\
\hline Age square & 1371.397 & 1379.453 & 1377.866 \\
\hline Marital status & 0.7453521 & 0.7200535 & 0.7250389 \\
\hline Work in Public sector & 0.7380282 & 0.413836 & 0.4777219 \\
\hline Years of schooling & 12.68004 & 9.759503 & 10.33075 \\
\hline Household size & 4.709296 & 5.362907 & 5.234106 \\
\hline Number of kids & 1.435936 & & 0.2719986 \\
\hline Number of durables in household & 10.29887 & 8.661305 & 8.971496 \\
\hline Household ownership & 1.81466 & 1.98099 & 1.949484 \\
\hline Number of rooms in household & 3.758343 & 3.640902 & 3.663148 \\
\hline Wealth score & 0.6141358 & 0.028466 & 0.1430961 \\
\hline Round of ELMPS survey & 2003.311 & 2003.93 & 2003.808 \\
\hline Greater Cairo & 0.3853521 & 0.284325 & 0.3042336 \\
\hline Urban lower & 0.1678873 & 0.1247638 & 0.1332618 \\
\hline Urban Upper & 0.1819718 & 0.1443978 & 0.1518022 \\
\hline Rural lower & 0.1971831 & 0.2481449 & 0.2381023 \\
\hline Rural upper & 0.0676056 & 0.1983684 & 0.1726001 \\
\hline No. Of observations & 5325 & 21697 & 27022 \\
\hline
\end{tabular}

Source: computed by the author using ELMPS 1998,2006, 2012.

Table 2: hourly wages by quintiles and gender 
Topics in Middle Eastern and African Economies

Proceedings of Middle East Economic Association

Vol. 19, Issue No. 2, September 2017

\begin{tabular}{lrrr} 
& Females & Males & \multicolumn{1}{l}{ Gap } \\
Q1 & 0.4324678 & 0.5533229 & 0.78158305 \\
Q2 & 1.063814 & 1.326808 & 0.801784433 \\
Q3 & 2.032023 & 2.361082 & 0.860632117 \\
Q4 & 3.680311 & 3.981868 & 0.924267454 \\
Q5 & 10.82764 & 11.49859 & 0.941649367 \\
\hline
\end{tabular}

Source: computed by the author using ELMPS 1998, 2006, 2012

Figure 1: Quintiles of hourly wages for females

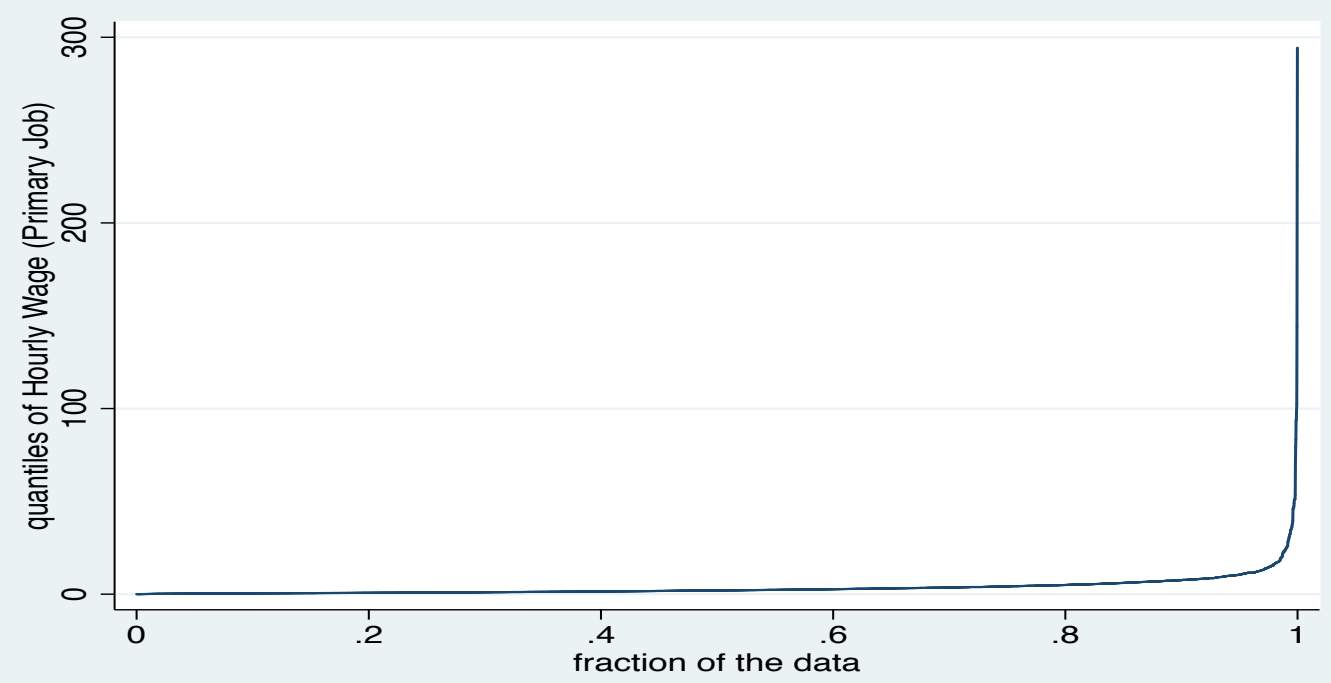

Source: computed by the author using ELMPS 1998, 2006, 2012

Figure 2: Quintiles of hourly wages for males 


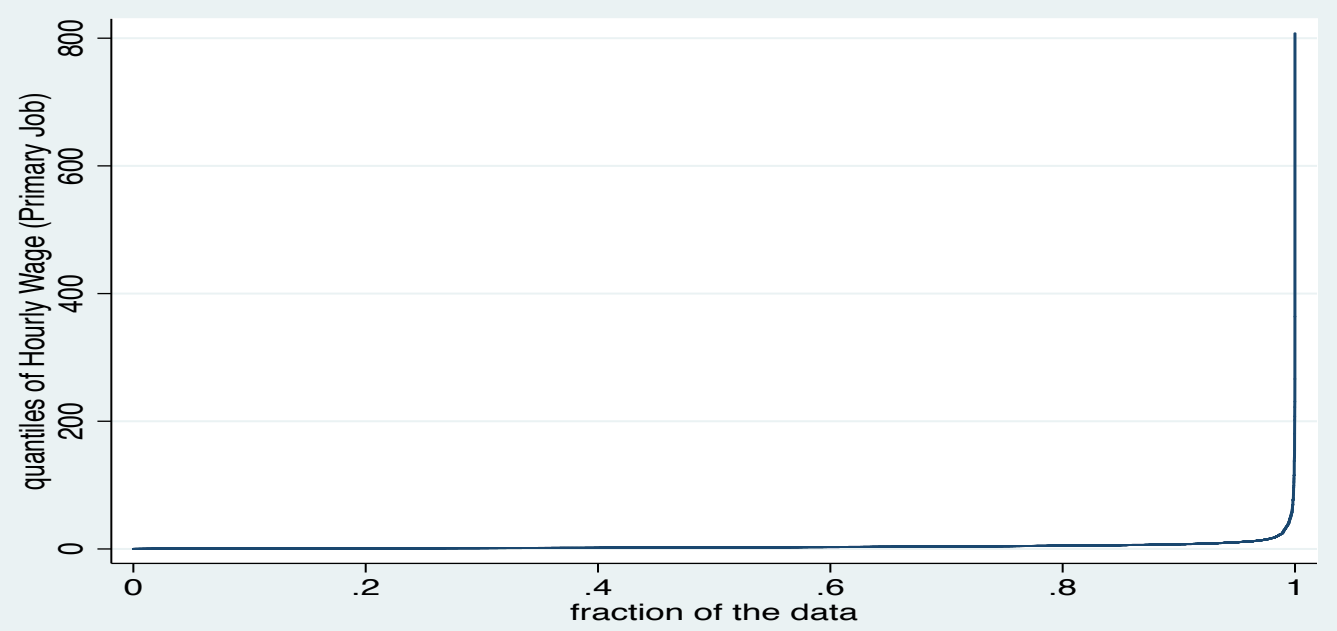

Source: computed by the author using ELMPS 1998, 2006, 2012

However the estimated unconditional gender wage gap suggest a different conclusion. The distribution of the estimated raw wage gap between males and female is depicted in Figure 3. This figure shows that the wage gap is in favor of men along most of the wage distribution but after the $80^{\text {th }}$ quintile the gap turns to be in favor of women. The gap decreases as we move along the wage distribution, until the $25^{\text {th }}$ quintile the gap seems to change very little to be around -0.25 while after that it decreases rapidly and at around the $80^{\text {th }}$ quintile the gap approaches zero and then we have a very narrow but increasing gap in favor of females. However as we approach the $90^{\text {th }}$ quintile the gap in favor of females starts to decrease. Thus this suggests that the discrimination against women in term of wages is focused at the very low and very high wage groups.

\section{Figure 3: Unconditional Gender Wage Gap:}




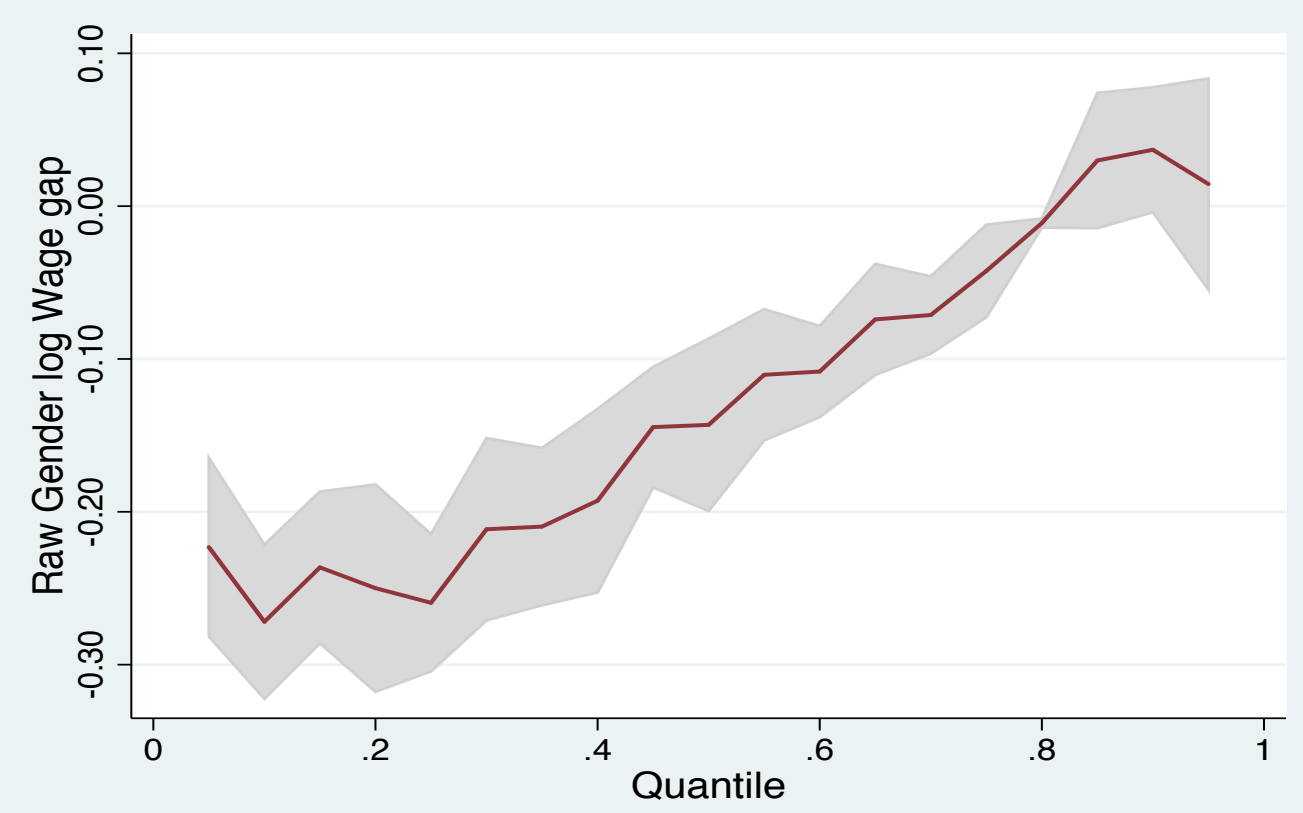

Source: computed by the author using ELMPS 1998, 2006, 2012

The graphs represent the raw female vs. male wage gap at different quantiles.

\section{4- Empirical Results:}

\section{4-1- OLS estimates:}

Table 3 display the estimated coefficient for three versions of the model estimated by pooled OLS. The first model includes no interaction terms, the second model include an interaction term between gender and round of survey to examine among those who remain working, if the gender gap is widening or closing. The third one include an interaction term between gender and years of schooling similarly to see if the effect of education level on the wage differs according to gender. Results show that in all three models female's hourly wage is significantly less than that of males in average. However the coefficients of the interaction terms in the second and the third models reveal an interesting story. In the second model although the wage gap in average is in favor of men it is decreasing with time. The significant positive coefficient for interaction between gender and round of survey indicates that women's wage increase more than men's wage with time, as the coefficient of round is positive. Specifically, in average each 
Topics in Middle Eastern and African Economies

Proceedings of Middle East Economic Association

Vol. 19, Issue No. 2, September 2017

year is worth about $0.94 \%$ more in wage for a woman than it is for a man. Similarly in model 3 although the wage gap in average is in favor of men it is decreasing with education. The significant positive coefficient for interaction between gender and years of education together with the positive significant coefficient of years of schooling indicates that females benefit more from education than do males. Specifically, in average each year of schooling is worth about $2.08 \%$ more for a female than it is for a male.

Table 3:

\begin{tabular}{lccc}
\hline & Model 1 & Model 2 & Model 3 \\
\hline Age & & & \\
& $0.0238^{* * *}$ & $0.0238^{* * *}$ & $0.0238^{* * *}$ \\
Age square & $(0.00317)$ & $(0.00317)$ & $(0.00317)$ \\
Gender & $-0.000128^{* * *}$ & $-0.000129^{* * *}$ & $-0.000129^{* * *}$ \\
& $(3.91 \mathrm{e}-05)$ & $(3.91 \mathrm{e}-05)$ & $(3.90 \mathrm{e}-05)$ \\
& $-0.278^{* * *}$ & $-19.25 * *$ & $-0.537^{* * *}$ \\
\hline
\end{tabular}


Topics in Middle Eastern and African Economies

Proceedings of Middle East Economic Association

Vol. 19, Issue No. 2, September 2017

\begin{tabular}{|c|c|c|c|}
\hline \multirow[t]{2}{*}{ Years of School } & $0.0211^{* * *}$ & $0.0211^{* * *}$ & $0.0187 * * *$ \\
\hline & $(0.00135)$ & $(0.00135)$ & $(0.00140)$ \\
\hline \multirow[t]{2}{*}{ Marital status } & $0.129 * * *$ & $0.128 * * *$ & $0.126^{* * *}$ \\
\hline & $(0.0162)$ & $(0.0162)$ & $(0.0162)$ \\
\hline \multirow[t]{2}{*}{ Sector of employment } & 0.000992 & -0.000367 & -0.00277 \\
\hline & $(0.0126)$ & $(0.0127)$ & $(0.0126)$ \\
\hline \multirow{2}{*}{ Interaction female and round } & & $0.00944 * *$ & \\
\hline & & $(0.00426)$ & \\
\hline \multirow{2}{*}{ Interaction female and years of schooling } & & & $0.0208 * * *$ \\
\hline & & & $(0.00307)$ \\
\hline \multirow{2}{*}{ Alex and Suez Canal } & -0.00546 & -0.00541 & -0.00608 \\
\hline & $(0.0197)$ & $(0.0197)$ & $(0.0197)$ \\
\hline \multirow{2}{*}{ Urban lower } & $-0.106 * * *$ & $-0.106^{* * *}$ & $-0.106 * * *$ \\
\hline & $(0.0198)$ & $(0.0198)$ & $(0.0197)$ \\
\hline \multirow[t]{2}{*}{ Urban Upper } & $-0.0530 * * *$ & $-0.0527 * * *$ & $-0.0567 * * *$ \\
\hline & $(0.0192)$ & $(0.0192)$ & $(0.0191)$ \\
\hline \multirow[t]{2}{*}{ Rural lower } & $-0.110 * * *$ & $-0.110 * * *$ & $-0.110 * * *$ \\
\hline & $(0.0189)$ & $(0.0189)$ & $(0.0189)$ \\
\hline \multirow[t]{2}{*}{ Rural upper. } & $0.0675 * * *$ & $0.0681 * * *$ & $0.0620 * * *$ \\
\hline & $(0.0210)$ & $(0.0210)$ & $(0.0210)$ \\
\hline \multirow[t]{2}{*}{ Round of survey (year) } & $0.120 * * *$ & $0.119 * * *$ & $0.120 * * *$ \\
\hline & $(0.00205)$ & $(0.00223)$ & $(0.00205)$ \\
\hline \multirow[t]{2}{*}{ Constant } & $-241.9 * * *$ & $-238.0 * * *$ & $-241.3 * * *$ \\
\hline & $(4.110)$ & $(4.468)$ & $(4.106)$ \\
\hline Observations & 17,641 & 17,641 & 17,641 \\
\hline R-squared & 0.367 & 0.367 & 0.368 \\
\hline
\end{tabular}

\section{4-2- Quintile regression estimates:}

Table 4:

\begin{tabular}{lcccc}
\hline OLS regression & $\begin{array}{c}\text { QR at 0.25 } \\
\text { Quantile }\end{array}$ & $\begin{array}{c}\text { QR at 0.5 } \\
\text { quantile }\end{array}$ & $\begin{array}{c}\text { QR at 0.75 } \\
\text { quantile }\end{array}$ \\
\hline Age & & & & \\
& $0.0238^{* * *}$ & $0.0214^{* * *}$ & $0.0184^{* * *}$ & $0.0119^{* * *}$ \\
\hline
\end{tabular}


Topics in Middle Eastern and African Economies

Proceedings of Middle East Economic Association

Vol. 19, Issue No. 2, September 2017

\begin{tabular}{|c|c|c|c|c|}
\hline \multirow[t]{2}{*}{ Age square } & $-0.000128 * * *$ & $-9.34 \mathrm{e}-05^{* *}$ & $-4.54 e-05$ & $3.93 \mathrm{e}-05$ \\
\hline & $(3.91 \mathrm{e}-05)$ & $(4.59 \mathrm{e}-05)$ & $(3.92 \mathrm{e}-05)$ & $(4.35 \mathrm{e}-05)$ \\
\hline \multirow[t]{2}{*}{ Gender } & $-0.278 * * *$ & $-0.288 * * *$ & $-0.257 * * *$ & $-0.259 * * *$ \\
\hline & $(0.0176)$ & $(0.0206)$ & $(0.0176)$ & $(0.0196)$ \\
\hline \multirow[t]{2}{*}{ Years of School } & $0.0211 * * *$ & $0.0248 * * *$ & $0.0208 * * *$ & $0.0183 * * *$ \\
\hline & $(0.00135)$ & $(0.00159)$ & $(0.00136)$ & $(0.00151)$ \\
\hline \multirow[t]{2}{*}{ Marital status } & $0.129 * * *$ & $0.161 * * *$ & $0.111 * * *$ & $0.0833 * * *$ \\
\hline & $(0.0162)$ & $(0.0190)$ & $(0.0162)$ & $(0.0180)$ \\
\hline \multirow[t]{2}{*}{$\begin{array}{l}\text { Sector of } \\
\text { employment }\end{array}$} & 0.000992 & -0.000149 & $-0.0231^{*}$ & $-0.0320 * *$ \\
\hline & $(0.0126)$ & $(0.0148)$ & $(0.0127)$ & $(0.0141)$ \\
\hline \multirow[t]{2}{*}{$\begin{array}{l}\text { Alex and Suez } \\
\text { Canal }\end{array}$} & -0.00546 & 0.0135 & 0.0255 & 0.00981 \\
\hline & $(0.0197)$ & $(0.0232)$ & $(0.0198)$ & $(0.0220)$ \\
\hline \multirow[t]{2}{*}{ Urban lower } & $-0.106^{* * *}$ & $-0.0822 * * *$ & $-0.0711 * * *$ & $-0.0910 * * *$ \\
\hline & $(0.0198)$ & $(0.0232)$ & $(0.0198)$ & $(0.0220)$ \\
\hline \multirow[t]{2}{*}{ Urban Upper } & $-0.0530 * * *$ & $-0.0472 * *$ & -0.0129 & $-0.0416^{*}$ \\
\hline & $(0.0192)$ & $(0.0225)$ & $(0.0192)$ & $(0.0213)$ \\
\hline \multirow[t]{2}{*}{ Rural lower } & $-0.110 * * *$ & $-0.107 * * *$ & $-0.0996 * * *$ & $-0.105 * * *$ \\
\hline & $(0.0189)$ & $(0.0222)$ & $(0.0189)$ & $(0.0210)$ \\
\hline \multirow[t]{2}{*}{ Rural upper. } & $0.0675^{* * *}$ & $0.0690 * * *$ & $0.0878 * * *$ & $0.0880 * * *$ \\
\hline & $(0.0210)$ & $(0.0246)$ & $(0.0210)$ & $(0.0234)$ \\
\hline \multirow[t]{2}{*}{$\begin{array}{l}\text { Round of survey } \\
\text { (year) }\end{array}$} & $0.120 * * *$ & $0.122 * * *$ & $0.128 * * *$ & $0.128 * * *$ \\
\hline & $(0.00205)$ & $(0.00241)$ & $(0.00206)$ & $(0.00229)$ \\
\hline \multirow[t]{2}{*}{ Constant } & $-241.9 * * *$ & $-246.2 * * *$ & $-257.8 * * *$ & $-256.2 * * *$ \\
\hline & $(4.110)$ & $(4.827)$ & $(4.121)$ & $(4.579)$ \\
\hline Observations & 17,641 & 17,641 & 17,641 & 17,641 \\
\hline
\end{tabular}

$* * * \mathrm{p}<0.01, * * \mathrm{p}<0.05, * \mathrm{p}<0.1$

Table 4 displays some of the estimated coefficients for gender (i.e. the wage gap) from the OLS regression and the quantile regression for the $25^{\text {th }}, 50^{\text {th }}$ and the $75^{\text {th }}$ quantiles ${ }^{1}$. The OLS results show that female's hourly wage is $27.8 \%$ less than that of males in average. Quantile regression results are very close to that of the OLS. Results show that females hourly wage is $28.8 \%$ less than that of males for those with low hourly wages (at the $25 \%$ quantile), $25.7 \%$ less for the middle quantile and $25.9 \%$ less for those with high hourly wages (at the $75 \%$ quantile). In other words, across quantiles the effect of being a female on hourly wages is negative i.e. its a penalty, however this gap is higher at the lower and highest quantiles as

${ }^{1}$ For the results of the whole coefficient see table in appendix. 
Topics in Middle Eastern and African Economies

Proceedings of Middle East Economic Association

Vol. 19, Issue No. 2, September 2017

compared to the middle ones.

Although the quantile coefficients are statistically significant than zero, they are significantly not different from the OLS coefficients (i.e. inside of the OLS 95\% confidence interval of [ $.3123567,-.2434392])$. This may suggest that OLS would do a good job estimating the gender wage gap in our case. However when looking at Figure 4 that shows the estimated gender wage gap at a more disaggregated wage distribution the picture is different. Figure 4 reports the estimated coefficient, the (conditional) gender wage gap, at the mean (OLS, long-dashed line) and at different quantiles (QR, solid line), together with the $95 \%$ confidence intervals (shortdashed lines for OLS and shaded area for QR). For the pooled OLS results show significant mean gender wage penalties at around $26 \%$. Turning to quantile estimations, we first notice that the conditional wage gap is not even along the distribution. With $\mathrm{QR}$, the overall trend is characterized by smaller penalties at the middle of the conditional distribution, and higher penalties at the bottom and top quantile. In other words, the largest penalties are to be found in the left and right tails of the conditional earnings distribution while penalties tend to decrease at the middle. Second we notice that the estimated coefficients for the very low quantiles $\left(10^{\text {th }}\right.$ quantile) are significantly different from the OLS coefficients. Which justify the use of the quantile regression.

Figure 4 displays the results in terms of sticky floors and glass ceilings. We use two alternative conditions to define a 'glass ceiling': if the $90^{\text {th }}$ percentile estimated wage gap is larger than that at the $75^{\text {th }}$ percentile or that at the $50^{\text {th }}$ percentile, 'Sticky floors' are defined in three ways: if the $10^{\text {th }}$ percentile estimated wage gap is larger than every other single estimated wage gap, the $75^{\text {th }}$ percentile estimated wage gap, or the estimated wage gap at the median. Accordingly, figure 4 indicates that there is evidence of glass ceiling as the estimated wage gap is larger than that at the $75^{\text {th }}$ percentile or that at the $50^{\text {th }}$ percentile. There is also clear evidence of sticky floors according to any of the three definitions used. Thus, this suggests that Egyptian females face both glass ceiling and sticky floors and that this is not solely an indication of occupational segregation or sectoral stratification. 


\section{Figure 4: Conditional Wage Gaps: OLS and QR Estimates}

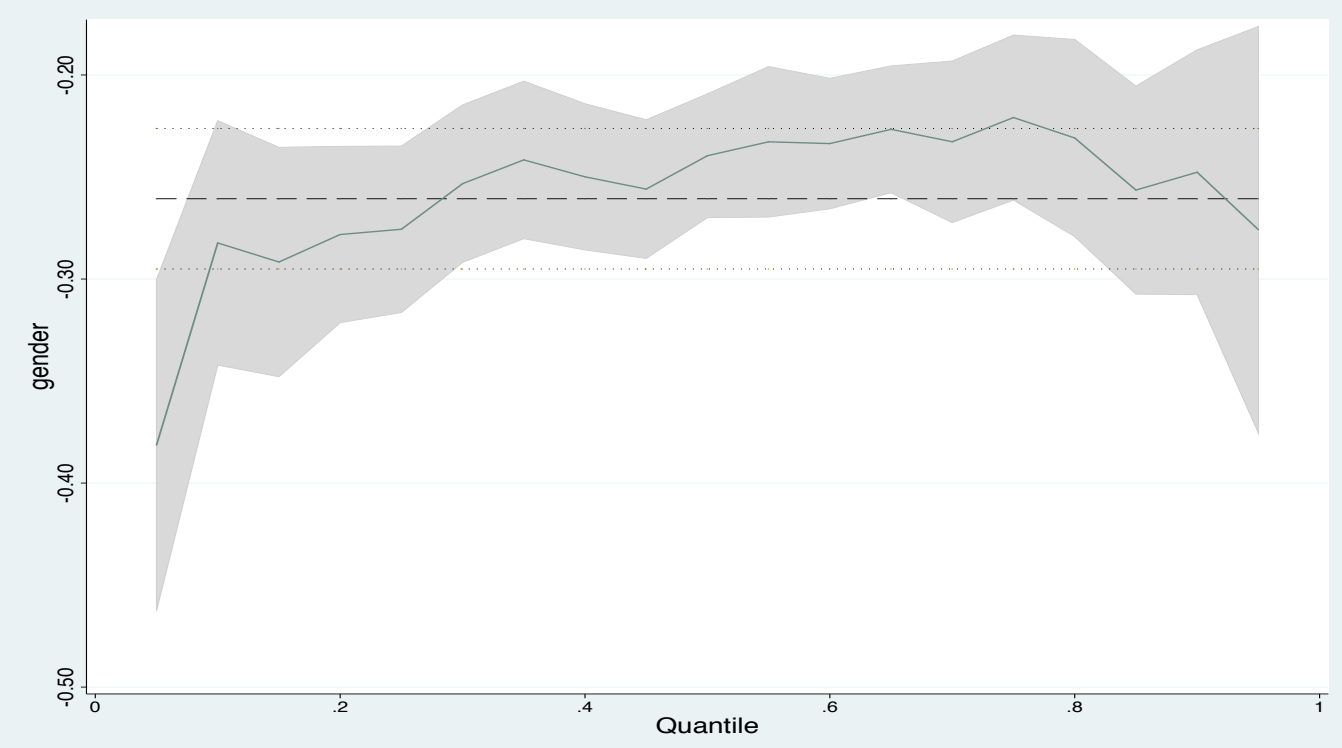

Source: Computed by the author

Figure $5 \mathrm{a}$ and $5 \mathrm{~b}$ displays the estimated coefficient, the conditional gender wage gap, at the mean (OLS) and at different quantiles (QR), together with the 95\% confidence intervals for two other versions of our model. The first model (figure 5a) includes only individual characteristics as regressors while the second model (figure 5b) includes household characteristics as well. Three comments are worth noting. First, when accounting for observed household characteristics in the second model the gender wage gape at the mean i.e. using pooled OLS is higher (29\%) than that of the model with individual characteristics only (20\%) and than that of our main model including regions and rounds as well.

Second, for the quantile regression results for the model including household characteristics are in general similar to our main model including all regressors; the conditional wage gap is not even along the distribution. The overall trend is characterized by lower penalties around the $20^{\text {th }}$ to $80^{\text {th }}$ quantile, higher penalties at the bottom of the conditional distribution and the top but the increase in the wage gap at the top is more obvious in the main model than the model with household characteristics. The model with individual characteristics only gives a different picture. It showed an increasing penalty for almost until the $20^{\text {th }}$ quintile a decreasing 
Topics in Middle Eastern and African Economies

Proceedings of Middle East Economic Association

Vol. 19, Issue No. 2, September 2017

penalty from the $20^{\text {th }}$ to the $85^{\text {th }}$ quintile and then an increase at the $90^{\text {th }}$ quintile. This might indicate that gender wage gap along the wage distribution is not attributed solely to individual characteristics but also to household characteristics and location.

Finally, we notice that moving from the model with individual characteristics only to the model with household characteristics as well to the main model including regions and rounds, the estimated coefficients of quantiles that is significantly different from the OLS estimates increased at the bottom quintile and decreased at the top. This may suggest that in general the difference in the gender wage gap along the wage distribution could be attributed to other unobservable other than gender itself and that the role of these unobservable varies along the wage distribution. For the higher quantiles accounting for household characteristics and region decreased the number of quintiles at which the quintile regression estimate is statistically significantly different than the pooled OLS estimate which may suggest that household characteristics and location matter for the gap at those higher quintile. While the opposite is true for the lower quintiles as the number of quintiles where quintile regression estimate is statistically significantly different than the pooled OLS estimate increased when moving from regression with individual characteristic to that with household characteristics then it decreased in the main model with regions, which may suggest that the gap at the lower quantiles is attributed to other unobservable related to location and social context.

Figure 5a and 5b: 

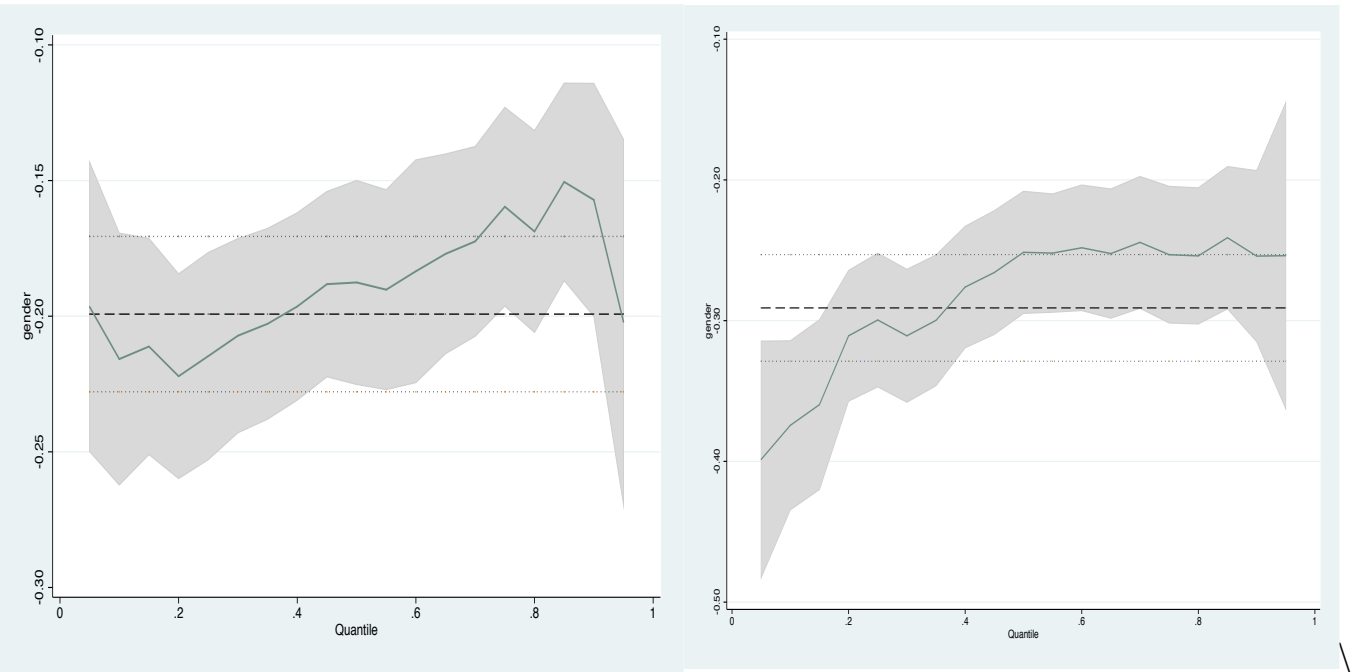

\section{5- Conclusion}

This paper examines the gender wage gaps along the wage distribution in Egypt using individual data from the labor market panel surveys 1998, 2006 and 2012 and a quantile regression approach.

Results using OLS show that female's hourly wage is significantly less than that of males in average. Female's hourly wage is $27.8 \%$ less than that of males in average. While the wage gap in average is in favor of men it is decreasing with time. Specifically, in average each year is worth about $0.94 \%$ more in wage for a woman than it is for a man. Moreover the wage gap in favoring of men is decreasing with education. Precisely, in average each year of schooling is worth about $2.08 \%$ more for a female than it is for a male.

Quantile regression results at the $10^{\text {th }}, 20^{\text {th }}, 40^{\text {th }}, 60^{\text {th }}$ and $80^{\text {th }}$ quantiles shows that across quantiles the effect of being a female on hourly wages is negative i.e. its a penalty, however this gap is higher at the lower and highest quantiles as compared to the middle ones. Indicating the presence of glass ceiling as well as sticky floors. Results also showed that comparing different versions of the regressions by moving from a model with only individual characteristics to the model with household characteristics as well to the main model including regions and rounds of survey suggests that household characteristics and location matter for the gap at higher quintile i.e. for the glass ceiling phenomena while the gap at the lower 
quantiles i.e. the sticky floor could be attributed to other unobservables related to location and social context. Which seems to be more important at the lower quintiles of the wage distribution. Social context may qualify males to compete better in the labor market. In societies like Egypt where women are less mobile and bear the responsibility for childbearing and where most formal organizations are considered to be masculine due to natural traits, this limits them from working late hours, commuting for long periods to reach a job, moving to places where jobs pay is higher, etc. Hence they lack features that permit a good "fit" into the job market. Accordingly women are being paid less for different reasons including not being employed in better paying jobs, being excluded from promotions, or they just chose to work into family friendly and/or socially appropriate, but low paying jobs, etc.).

Thus, key policy options must include not simply the usual policies to improve women's productivity (increasing women's human capital, access to finance, etc.). But policies that encourages gender equity in hiring, and in the job markets and hence decreases time women have to spend out of the labor force (such as providing day-care centers and nurseries at the work place, allowing for parental leave, compliance with maternity regulations). Moreover, policy options need to be extended out of the labor market and into the household to help women overcome unobservables that trap them in low-paying jobs.

Another important finding of this study is that there are sticky floors, as well as glass ceiling in the Egyptian labor market. This is critical for equity and poverty-reduction consideration. Policies to reduce poverty and break the link between gender and poverty are focused on helping self-employed females to access credit and information. Though this is certainly important, the study shows that gender wage differences harm the poor the most. Thus, more attention should be given to policies tackling gender inequalities at the bottom of the distribution 
Topics in Middle Eastern and African Economies

Proceedings of Middle East Economic Association

Vol. 19, Issue No. 2, September 2017

\section{References}

Aktas, Arda and Uysal. Gokce. (2012). "Explaining the Gender Wage Gap in Turkey Using the Wage Structure Survey”. Betam Working Paper Series no 005, Center for Economic and Social Research, Bahcesehir University, March.

Albrecht, James, Anders Bjorklund, and Susan Vroman. 2003. "Is There a Glass Ceiling in Sweden?"Journal of Labour Economics 21 (1): 145-177.

Anker, R. (1997), “Theories of occupational segregation by sex: an overview”, International Labour Review, Vol. 136 No. 3, pp. 315-39.

Arabsheibani, Reza (2000). "Male-Female Earnings Differentials Among the Highly Educated Egyptians", Education Economics, vol 8 no2, 129-138.

Arulampalam, Wiji, Alison L. Booth and Mark L. Bryan. (2006). "Is there a Glass Ceiling over Europe? Exploring the Gender Pay Gap across the Wages Distribution." Discussion Paper No. 510, Centre for Economic Policy Research, Research School of Social Science, Australia National University.

Ashraf, J. and Ashraf, B. (1998), "Earnings in Karachi: does gender make a difference", Pakistan Economic and Social Review, Vol. 36 No. 1, pp. 33-46.

Assaad, R., \& Krafft, C. (2015). The structure and evolution of employment in Egypt: 19982012. The Egyptian Labor Market in an Era of Revolution, 27-51.

Derek, R. (1998), "Differences in occupational earnings by sex", International Labour Review, Vol. 137, p. 331.

El Badaoui, E., Strobl, E., \& Walsh, F. (2008). Is there an informal employment wage penalty? Evidence from South Africa. Economic Development and Cultural Change, 56(3), 683710.

Deaton, A.(1997) The Analysis of Household Surveys (Maryland: The John Hopkins University Press for the World Bank).

De la Rica, S., \& Iza, A. (2005). Career planning in spain: do fixed-term contracts delay marriage and parenthood?. Review of Economics of the Household, 3(1), 49-73.

El-Hamidi, Fatma and Said, Mona. (2005). "Wage inequality and Gender in MENA: Contrasting the Egyptian and Moroccan Experiences in the 1990sERF, Egypt.

El-Hamidi, Fatma and Said, Mona. (2008). "Have Economic Reforms Paid-off? Gender Occupational Inequality in The New Millennium in Egypt", ECES, Egypt.

Elizabeth, B. (1998), "Winners and losers in Russia's economic transition", The American Economic Review, Vol. 88 No. 5, pp. 1094 - 116. 
Ermisch, J.F., Josh, H. and Wright, R.E. (1990), "Women wages in Great Britain", Birkbeck College Discussion Papers in Economics, 8/90.

Francois, P. (1995), "A theory of gender discrimination based on the household", Queens Institute for the Economics discussion papers.

Gunewardena, D., Abeyrathna, D., Ellagala, A., Rajakaruna, K., \& Rajendran, S. (2008). “Glass ceilings, sticky floors or sticky doors? A quantile regression approach to exploring gender wage gaps in Sri Lanka." PMMA Working Paper 2008-04.

Hampton, M.B. and Heywood, J.S. (1993), "Do workers accurately perceive gender wage discrimination?", Industrial \& Labor Relations Review, Vol. 47, pp. 35-49.

Harkness, S. (1996), “The gender earnings gap: evidence from the UK”, Fiscal Studies, Vol. 17 No. 2, pp. 1-15.

Hoffner, E. and Greene, M. (1997), "Gender discrimination in the public and private sectors: a sample selectivity approach”, Journal of Socio-Economics, Vol. 25 No. 1, pp. 105-14.

Kandil Lamia, E. (2009). "Gender Wage Discrimination in Egypt: A Quantile Regression Analysis." Paris: Université Paris I Panthéon-Sorbonne.

Kara, O (2006),"Occupational gender wage discrimination in Turkey", Journal of Economic Studies, Vol. 33 Iss 2 pp. $130-143$.

Koenker, R. and G. Bassett. (1978). “Regression Quantiles.”Econometrica 46:33-50.

Koenker, R. and Hallock, K. (2001). “Quantile Regression.” Journal of Economic Perspectives 14 (4): 143-156.

Montenegro, C. (2001). "Wage Distribution in Chile: Does Gender Matter? A Quantile Regression Approach.” Policy Research Report on Gender and Development Working Paper Series No. 20.

Newell, A. and Reilly, B. (2001). "The Gender Pay Gap in the Transition from Communism: Some Empirical Evidence.” Economic Systems 25(4): 287-304.

Nor, L.M. (1998), “An overview of gender earning differentials in peninsular Malaysia", Journal of Economics \& Management, Vol. 6 No. 1, pp. 23-49.

Pendakur, K., \& Pendakur, R. (2007). "Minority earnings disparity across the distribution. Canadian Public Policy.” 33(1), 41-61.

Pham, T. H. and Reilly B. (2006.) “The Gender Pay Gap in Vietnam, 1993-2002: A Quantile Regression Approach.” PRUS Working Paper no. 34, July 2006.

Pouliakas, I., (2012),"Educational segregation and the gender wage gap in Greece", Journal of Economic Studies, Vol. 39 Iss 5 pp. $554-575$. 
Said, M. (2003). "The Distribution of Gender and Public Sector Pay Premia: Evidence from the Egyptian Organized Sector". Department of Economics Working Papers No.132, School of Oriental and African Studies University of London.

Said, Mona (2007). "The Fall and Rise of Earnings and Inequality in Egypt: New Evidence from the EIMPS 2006" ERF Working Paper no 0708, Economic Research Forum, October.

Said, M. (2015). "Wages and Inequality in the Egyptian Labor Market in an Era of Financial Crisis and Revolution", ERF Working Paper no 912, Economic Research Forum, May 2015.

Sakellariou, C. (2004). "The use of quantile regressions in estimating gender wage differentials: a case study of the Philippines." Applied Economics 36, 1001-1007.

Schafgans, M.M.A. (1997), Gender Wage Differences in Malaysia; Parametric and Semiparametric Estimation, STICERD, London School of Economics discussion papers services. EM/97 - 325.

Schultz, T.W. (1959). "Investment in man: an economist view”, Social Science Review, Vol. 33, pp. 109-17.

Schultz, T.W. (1960). “Capital formation by education”, Journal of Political Economy, Vol. 68 No. 6, pp. 571-83.

Schultz, T.W. (1961), "Investment in human capital”, American Economic Review, Vol. 51, pp. $1-17$.

Singh, M. and Bhattarcherjee, D. (1998), "Pay discrimination by gender in corporate sector: a case study", Indian Journal of Labour Economics, Vol. 41 No. 1, pp. 97-103.

Stephen, M. (1998), "Recent shifts in wage inequality and the wage returns to education in Britain”, National Institute Economic Review, Vol. 166, pp. 87-95.

Tannuri-Pianto, M., Pianto, D. and Arias, O. (2004). "Informal Employment in Bolivia: A Lost Proposition?” in Econometric Society Series, Econometric Society, Latin American Meetings, No. 149.

Tansel, A. (2004). "Public-Private Employment Choice, Wage Differentials and Gender in Turkey." IZA Discussion paper series no. 1262, August.

Teo, S. (2003). "Occupational Segregation and its Effect on Estimates of Gender Wage Differential: Evidence from Brunei.” Asian Economic Journal vol17 no. 4.

Terrell, K. (1992). "Female-male earning differentials and occupational structure", International Labour Review, Vol. 131, pp. 387-98. 
Weeden, KA. (1998). "Revisiting occupational sex segregation in the United States, 19101990: results from a log-linear approach.” Demography, Vol. 35 No 4, pp. 475-487

\section{Appendix}

Table A-1: Pooled OLS

(1)

(2)

(3)

lhrwg

lhrwg

lhrwg

\begin{tabular}{|c|c|c|c|}
\hline VARIABLES & lhrwg & lhrwg & lhrwg \\
\hline \multicolumn{4}{|l|}{ Individual characteristics: } \\
\hline \multirow[t]{3}{*}{ Age } & $0.0238 * * *$ & $0.0238 * * *$ & $0.0238^{* * *}$ \\
\hline & $(0.00317)$ & $(0.00317)$ & $(0.00317)$ \\
\hline & - & - & - \\
\hline \multirow[t]{2}{*}{ Age square } & $0.000128 * * *$ & $0.000129 * * *$ & $0.000129 * * *$ \\
\hline & $(3.91 \mathrm{e}-05)$ & $(3.91 \mathrm{e}-05)$ & $(3.90 \mathrm{e}-05)$ \\
\hline \multirow[t]{2}{*}{ Gender $($ reference $=$ male $)$} & $-0.278 * * *$ & $-19.25 * *$ & $-0.537 * * *$ \\
\hline & $(0.0176)$ & $(8.552)$ & $(0.0422)$ \\
\hline \multirow[t]{2}{*}{ Marital status (reference $=$ single) } & $0.129 * * *$ & $0.128 * * *$ & $0.126 * * *$ \\
\hline & $(0.0162)$ & $(0.0162)$ & $(0.0162)$ \\
\hline \multirow[t]{2}{*}{ Sector of employment (reference $=$ private $)$} & 0.000992 & -0.000367 & -0.00277 \\
\hline & $(0.0126)$ & $(0.0127)$ & $(0.0126)$ \\
\hline \multirow[t]{2}{*}{ Years of School } & $0.0211 * * *$ & $0.0211 * * *$ & $0.0187 * * *$ \\
\hline & $(0.00135)$ & $(0.00135)$ & $(0.00140)$ \\
\hline \multicolumn{4}{|l|}{ Father's education (reference: illiterate) } \\
\hline \multirow[t]{2}{*}{ Read \& write } & 0.0170 & 0.0172 & 0.0174 \\
\hline & $(0.0138)$ & $(0.0138)$ & $(0.0138)$ \\
\hline \multirow[t]{2}{*}{ Less than intermediate } & $0.0422 * *$ & $0.0422 * *$ & $0.0412 * *$ \\
\hline & $(0.0166)$ & $(0.0166)$ & $(0.0166)$ \\
\hline \multirow[t]{2}{*}{ Intermediate } & 0.0307 & 0.0305 & 0.0298 \\
\hline & $(0.0214)$ & $(0.0214)$ & $(0.0214)$ \\
\hline \multirow[t]{2}{*}{ Higher than intermediate } & 0.0667 & 0.0661 & 0.0638 \\
\hline & $(0.0407)$ & $(0.0407)$ & $(0.0406)$ \\
\hline \multirow[t]{2}{*}{ University } & $0.130 * * *$ & $0.130 * * *$ & $0.125 * * *$ \\
\hline & $(0.0282)$ & $(0.0282)$ & $(0.0282)$ \\
\hline \multirow[t]{2}{*}{ Post-graduate } & 0.0407 & 0.0433 & 0.0300 \\
\hline & $(0.0915)$ & $(0.0915)$ & $(0.0914)$ \\
\hline \multicolumn{4}{|l|}{ Mother's education (reference: illiterate) } \\
\hline \multirow[t]{2}{*}{ Read \& write } & 0.00278 & 0.00344 & 0.00112 \\
\hline & $(0.0183)$ & $(0.0183)$ & $(0.0183)$ \\
\hline \multirow[t]{2}{*}{ Less than intermediate } & -0.0202 & -0.0207 & -0.0230 \\
\hline & $(0.0210)$ & $(0.0210)$ & $(0.0210)$ \\
\hline \multirow[t]{2}{*}{ Intermediate } & $-2.60 \mathrm{e}-10$ & -0.00103 & -0.00709 \\
\hline & $(0.0268)$ & $(0.0268)$ & $(0.0268)$ \\
\hline
\end{tabular}


Topics in Middle Eastern and African Economies

Proceedings of Middle East Economic Association

Vol. 19, Issue No. 2, September 2017

Higher than intermediate

University

$\begin{array}{ccc}-0.0582 & -0.0585 & -0.0623 \\ (0.0562) & (0.0562) & (0.0561) \\ 0.0788^{*} & 0.0775^{*} & 0.0720^{*} \\ (0.0413) & (0.0413) & (0.0413) \\ 0.235 & 0.231 & 0.230 \\ (0.189) & (0.189) & (0.188)\end{array}$

Household Characteristics

Total number of Individuals in the Household

$\begin{array}{ccc}-0.0132 * * * & -0.0133 * * * & -0.0135 * * * \\ (0.00266) & (0.00266) & (0.00266) \\ 0.0241 * * * & 0.0241 * * * & 0.0272 * * * \\ (0.00766) & (0.00766) & (0.00766) \\ 0.00790 * * & 0.00823 * * & 0.00812 * * \\ (0.00385) & (0.00385) & (0.00384)\end{array}$

Dwelling ownership (reference: rented)

Owned

$\begin{array}{ccc}0.0343 * * & 0.0337 * * & 0.0334 * * \\ (0.0138) & (0.0138) & (0.0138) \\ -2.38 \mathrm{e}-05 & 9.56 \mathrm{e}-05 & 0.000919 \\ (0.0177) & (0.0177) & (0.0177) \\ 0.0110 * * & 0.0110 * * & 0.0110 * * \\ (0.00492) & (0.00492) & (0.00491) \\ 0.144 * * * & 0.143 * * * & 0.142 * * * \\ (0.0139) & (0.0139) & (0.0139)\end{array}$

\section{Regions (reference: Greater Cairo)}

Alex and Suez Canal

$\begin{array}{ccc}-0.00546 & -0.00541 & -0.00608 \\ (0.0197) & (0.0197) & (0.0197) \\ -0.106 * * * & -0.106 * * * & -0.106 * * * \\ (0.0198) & (0.0198) & (0.0197) \\ -0.0530 * * * & -0.0527 * * * & -0.0567 * * * \\ (0.0192) & (0.0192) & (0.0191) \\ -0.110 * * * & -0.110 * * * & -0.110 * * * \\ (0.0189) & (0.0189) & (0.0189) \\ 0.0675 * * * & 0.0681 * * * & 0.0620 * * * \\ (0.0210) & (0.0210) & (0.0210) \\ 0.120 * * * & 0.119 * * * & 0.120 * * * \\ (0.00205) & (0.00223) & (0.00205)\end{array}$

Interaction female and round

Interaction female and years of schooling

Constant

$-241.9 * * *$

(4.110)
$(0.00307)$ $-241.3^{* * *}$ (4.106) 
Observations

17,641

17,641

17,641

R-squared

0.367

0.367

0.368

Table A-2: Pooled and quintile regression estimates:

\begin{tabular}{|c|c|c|c|c|}
\hline VARIABLES & $\begin{array}{l}\text { OLS } \\
\text { regression }\end{array}$ & $\begin{array}{c}\text { QR } \\
\text { at } 0.25 \\
\text { Quantile }\end{array}$ & $\begin{array}{l}\text { QR at } 0.5 \\
\text { quantile }\end{array}$ & $\begin{array}{l}\text { QR at } 0.75 \\
\text { quantile }\end{array}$ \\
\hline Age & $\begin{array}{c}0.0238 * * * \\
(0.00317)\end{array}$ & $\begin{array}{c}0.0214 * * * \\
(0.00372)\end{array}$ & $\begin{array}{r}0.0184 * * * \\
(0.00318)\end{array}$ & $\begin{array}{r}0.0119 * * * \\
(0.00353)\end{array}$ \\
\hline Age square & $\begin{array}{c}-0.000128 * * * \\
(3.91 \mathrm{e}-05)\end{array}$ & $\begin{array}{c}-9.34 \mathrm{e}-05^{* *} \\
(4.59 \mathrm{e}-05)\end{array}$ & $\begin{array}{l}-4.54 \mathrm{e}-05 \\
(3.92 \mathrm{e}-05)\end{array}$ & $\begin{array}{c}3.93 \mathrm{e}-05 \\
(4.35 \mathrm{e}-05)\end{array}$ \\
\hline $\begin{array}{l}\text { Gender (reference } \\
=\text { male) }\end{array}$ & $\begin{array}{c}-0.278 * * * \\
(0.0176)\end{array}$ & $\begin{array}{c}-0.288 * * * \\
(0.0206)\end{array}$ & $\begin{array}{c}-0.257 * * * \\
(0.0176)\end{array}$ & $\begin{array}{c}-0.259 * * * \\
(0.0196)\end{array}$ \\
\hline $\begin{array}{l}\text { Marital status } \\
\text { (reference }=\text { single) }\end{array}$ & $\begin{array}{l}0.129 * * * \\
(0.0162)\end{array}$ & $\begin{array}{l}0.161 * * * \\
(0.0190)\end{array}$ & $\begin{array}{l}0.111 * * * \\
(0.0162)\end{array}$ & $\begin{array}{c}0.0833 * * * \\
(0.0180)\end{array}$ \\
\hline $\begin{array}{l}\text { Sector of } \\
\text { employment } \\
\text { (reference= } \\
\text { private) }\end{array}$ & 0.000992 & -0.000149 & $-0.0231 *$ & $\begin{array}{r}-0.0320 * * \\
(0.0141)\end{array}$ \\
\hline $\begin{array}{l}\text { Years of } \\
\text { Schooling }\end{array}$ & $\begin{array}{l}0.0211 * * * \\
(0.00135)\end{array}$ & $\begin{array}{l}0.0248 * * * \\
(0.00159)\end{array}$ & $\begin{array}{c}0.0208 * * * \\
(0.00136)\end{array}$ & $\begin{array}{c}0.0183 * * * \\
(0.00151)\end{array}$ \\
\hline $\begin{array}{l}\text { Father's } \\
\text { education } \\
\text { (reference: } \\
\text { illiterate) }\end{array}$ & & & & \\
\hline Read \& write & $\begin{array}{c}0.0170 \\
(0.0138)\end{array}$ & $\begin{array}{c}0.0183 \\
(0.0162)\end{array}$ & $\begin{array}{c}0.0207 \\
(0.0139)\end{array}$ & $\begin{array}{c}0.0218 \\
(0.0154)\end{array}$ \\
\hline $\begin{array}{l}\text { Less than } \\
\text { intermediate }\end{array}$ & $0.0422 * *$ & 0.0167 & 0.0171 & $0.0357 *$ \\
\hline & $(0.0166)$ & $(0.0195)$ & $(0.0166)$ & $(0.0185)$ \\
\hline Intermediate & $\begin{array}{c}0.0307 \\
(0.0214)\end{array}$ & $\begin{array}{c}0.0182 \\
(0.0252)\end{array}$ & $\begin{array}{c}0.0143 \\
(0.0215)\end{array}$ & $\begin{array}{l}0.0425^{*} \\
(0.0239)\end{array}$ \\
\hline Higher than & 0.0667 & 0.0262 & 0.00633 & 0.0536 \\
\hline & $(0.0407)$ & $(0.0477)$ & $(0.0408)$ & $(0.0453)$ \\
\hline University & $\begin{array}{l}0.130 * * * \\
(0.0282)\end{array}$ & $\begin{array}{c}0.0409 \\
(0.0332)\end{array}$ & $\begin{array}{l}0.101 * * * \\
(0.0283)\end{array}$ & $\begin{array}{l}0.179 * * * \\
(0.0315)\end{array}$ \\
\hline Post-graduate & 0.0407 & 0.00473 & 0.0731 & -0.0165 \\
\hline
\end{tabular}




\section{Mother's \\ education \\ (reference: \\ illiterate)}

Read \& write

Less than

intermediate

Intermediate

Higher than

intermediate

University

Post-graduate

\section{Household}

Characteristics

Total number of

Individuals in the

Household

Number of kids

Number of

durables

Dwelling

ownership

(reference: rented)

Owned

Provided free

Number of rooms

in the house

Household wealth score
$(0.0915) \quad(0.107) \quad(0.0917)$

$(0.102)$

$\begin{array}{cccc}0.00278 & 0.0291 & 0.0206 & 0.0159 \\ 0.0183) & (0.0215) & (0.0183) & (0.0204) \\ -0.0202 & -0.0223 & -0.0324 & 0.0163 \\ 0.0210) & (0.0247) & (0.0211) & (0.0234) \\ -2.60 \mathrm{e}-10 & -0.0259 & -0.00619 & 0.0448 \\ 0.0268) & (0.0314) & (0.0268) & (0.0298) \\ -0.0582 & -0.0866 & -0.0560 & -0.0365 \\ 0.0562) & (0.0660) & (0.0563) & (0.0626) \\ 0.0788^{*} & 0.0881 * & 0.0792 * & 0.151^{* * *} \\ 0.0413) & (0.0485) & (0.0414) & (0.0460) \\ 0.235 & 0.477 * * & 0.190 & 0.459 * * \\ (0.189) & (0.222) & (0.189) & (0.210)\end{array}$

$-0.0132 * * *$

$-0.0106^{* * *}$

$-0.00807 * * *$

$-0.0102 * * *$

$(0.00266)$

$0.0241 * * *$

$(0.00313)$

$0.0434 * * *$

(0.00267)

$0.0368 * * *$

(0.00297)

(0.00766)

(0.00900)

(0.00768)

$0.0305 * * *$

(0.00854)

0.00790 **

0.00136

0.00492

$0.0107 * *$

(0.00385)

(0.00452)

(0.00386)

(0.00428)

$0.0343 * *$

0.0237

$0.0397 * * *$

$0.0385 * *$

(0.0138)

$(0.0162)$

(0.0139)

(0.0154)

$-2.38 \mathrm{e}-05$

$-0.00889$

0.0178

0.00112

(0.0177)

(0.0208)

(0.0178)

(0.0198)

$0.0110 * *$

0.00624

0.00290

0.00656

(0.00492)

(0.00578)

(0.00493)

(0.00548)

$0.144 * * *$

$0.153 * * *$

$0.154 * * *$

$0.130 * * *$

(0.0139)

(0.0163)

(0.0139)

(0.0155) 
Topics in Middle Eastern and African Economies

Proceedings of Middle East Economic Association

Vol. 19, Issue No. 2, September 2017

\begin{tabular}{|c|c|c|c|c|}
\hline \multicolumn{5}{|l|}{$\begin{array}{l}\text { Regions } \\
\text { (reference: } \\
\text { Greater Cairo) }\end{array}$} \\
\hline $\begin{array}{l}\text { Alex and Suez } \\
\text { Canal }\end{array}$ & -0.00546 & 0.0135 & 0.0255 & 0.00981 \\
\hline & $(0.0197)$ & $(0.0232)$ & $(0.0198)$ & $(0.0220)$ \\
\hline Urban lower & $\begin{array}{c}-0.106^{* * * *} \\
(0.0198)\end{array}$ & $\begin{array}{c}-0.0822 * * * \\
(0.0232)\end{array}$ & $\begin{array}{c}-0.0711^{* * *} \\
(0.0198)\end{array}$ & $\begin{array}{c}-0.0910 * * * \\
(0.0220)\end{array}$ \\
\hline Urban Upper & $\begin{array}{c}-0.0530 * * * \\
(0.0192)\end{array}$ & $\begin{array}{c}-0.0472 * * \\
(0.0225)\end{array}$ & $\begin{array}{l}-0.0129 \\
(0.0192)\end{array}$ & $\begin{array}{l}-0.0416^{*} \\
(0.0213)\end{array}$ \\
\hline Rural lower & $\begin{array}{c}-0.110 * * * \\
(0.0189)\end{array}$ & $\begin{array}{c}-0.107 * * * \\
(0.0222)\end{array}$ & $\begin{array}{c}-0.0996 * * * \\
(0.0189)\end{array}$ & $\begin{array}{c}-0.105 * * * \\
(0.0210)\end{array}$ \\
\hline Rural upper. & $\begin{array}{c}0.0675 * * * \\
(0.0210)\end{array}$ & $\begin{array}{c}0.0690 * * * \\
(0.0246)\end{array}$ & $\begin{array}{c}0.0878 * * * \\
(0.0210)\end{array}$ & $\begin{array}{c}0.0880 * * * \\
(0.0234)\end{array}$ \\
\hline $\begin{array}{l}\text { Round of survey } \\
\text { (year) }\end{array}$ & $0.120 * * *$ & $0.122 * * *$ & $0.128 * * *$ & $0.128 * * *$ \\
\hline & $(0.00205)$ & $(0.00241)$ & $(0.00206)$ & $(0.00229)$ \\
\hline Constant & $\begin{array}{c}-241.9 * * * \\
(4.110)\end{array}$ & $\begin{array}{c}-246.2 * * * \\
(4.827)\end{array}$ & $\begin{array}{c}-257.8 * * * \\
(4.121)\end{array}$ & $\begin{array}{c}-256.2 * * * \\
(4.579)\end{array}$ \\
\hline Observations & 17,641 & 17,641 & 17,641 & 17,641 \\
\hline R-squared & 0.367 & & & \\
\hline
\end{tabular}

Standard errors in parentheses

$* * * \mathrm{p}<0.01, * * \mathrm{p}<0.05, * \mathrm{p}<0.1$ 